\title{
Refractive errors and accommodative insufficiency in children with learning difficulties
}

\section{Errores de refracción y alteraciones acomodativas en niños con dificultades en el aprendizaje}

\author{
Andrea Rangel-Padilla*, Juan H. Paéz-Garza, Antonella Royero-Alemán, Sylvia De la Rosa-Pacheco, and \\ María T. Rodríguez-Neira \\ Escuela de Medicina y Ciencias de la Salud, Tecnológico de Monterrey, Monterrey, Nuevo Leon, Mexico
}

\begin{abstract}
Background: The first cause of school failure is learning disabilities. Diagnosis and treatment require a multidisciplinary approach in which it is important to rule out any ophthalmological condition that can interfere with the learning process. There is no data about this condition in the Mexican population; therefore, it is important to evaluate the most common visual defects. Purpose: To describe ophthalmological findings in children with learning difficulties. Method: The following data was retrieved from a retrospective review of the medical records of children aged 5 to 16 years with learning difficulties who underwent eye examinations from January 2018 through January 2019. The records include the following variables: age, gender, visual acuity, ocular alignment, fusion, stereoacuity, near point of convergence, color vision, accommodative amplitude, cycloplegic refraction, slit lamp, fundus exam, and diagnosis. Results: Data from 69 children were included, their mean age was 9.3 years $( \pm 3.5), 51$ of them were men. Ophthalmic findings were made in 39 of the 69 children included: 22 patients presented with significant refractive error, 10 patients had accommodative insufficiency, 10 patients showed convergence insufficiency. Other diagnoses found were strabismus, amblyopia, allergic conjunctivitis, and color blindness. Conclusions: It is advisable that every child with learning difficulties should go through an extensive eye examination including accommodation and vergence tests to rule out any visual defects that can interfere with learning.
\end{abstract}

Keywords: Refractive errors. Accommodative insufficiency. Learning disabilities. Children.

\section{Resumen}

Introducción: Las dificultades en el aprendizaje se consideran la primera causa de fracaso escolar. Se requiere un abordaje multidisciplinario para su diagnóstico y tratamiento. Dentro de la batería de estudios se encuentra la valoración oftalmológica con el objetivo de descartar algún problema asociado que pueda interferir en el proceso de aprendizaje. Existe información limitada sobre el estado visual de los pacientes con dificultades de aprendizaje en nuestra población, por lo que es de importancia evaluar las alteraciones oftalmológicas que con más frecuencia se encuentran. Objetivo: Describir las alteraciones oftalmológicas encontradas en niños con dificultades de aprendizaje referidos para evaluación oftalmológica. Método: Estudio transversal observacional en el que se incluyeron 69 pacientes de 5 a 16 años, referidos desde una institución de educación que brinda apoyo a niños con dificultades de aprendizaje para valoración oftalmológica, en el

Correspondence:

*Andrea Rangel-Padilla

Batallón de San Patricio $112,1^{\circ}$ ote.

Col. Real de San Agustín, 66278 Date of reception: 12-04-2021

San Pedro Garza García, Nuevo Leon, Mexico Date of acceptance: 02-09-2021

E-mail: andrearp@tec.mx

DOI. 10.24875/RMOE.M21000201
Available online: 31-01-2022

Rev Mex Oftalmol (Eng). 2022;96(1):3-8

www.rmo.com.mx

2604-1731/@ 2021 Sociedad Mexicana de Oftalmología. Published by Permanyer. This is an open access article under the CC BY-NC-ND license (http://creativecommons.org/licenses/by-nc-nd/4.0/). 
período comprendido de enero de 2018 a enero de 2019. De los expedientes clínicos se tomaron las siguientes variables: sexo, edad, agudeza visual, alineación ocular, fusión sensorial, estereoagudeza, punto próximo de convergencia, visión de colores, amplitudes acomodativas, refracción ciclopléjica, biomicroscopía, fundoscopía y diagnóstico. Resultados: Se analizaron datos de 69 pacientes con un promedio de edad de 9.3 años ( \pm 3.5$)$, de los que 51 eran de sexo masculino. Presentaron alguna alteración oftalmológica 38 pacientes, encontrando errores de refracción en 22, insuficiencia acomodativa en 10 e insuficiencia de convergencia en 10. Otras alteraciones encontradas en menor proporción fueron estrabismo, ambliopía, conjuntivitis alérgica y daltonismo. Conclusiones: En los niños con dificultades escolares consideramos importante realizar una exploración oftalmológica exhaustiva que incluya las vergencias y la acomodación con el fin de identificar factores visuales que pudieran interferir en el proceso de aprendizaje.

Palabras clave: Errores refractivos. Insuficiencia acomodativa. Dificultades de aprendizaje. Niños.

\section{Introduction}

Learning problems are considered the first cause of school failure ${ }^{1}$. They are one heterogeneous group of disorders that make children whose intelligence is on average have problems processing information or formulating answers, thus affecting neurocognitive processes, which expresses itself as impaired pronunciation, understanding, reading-writing skills, mathematic problem-solving, and organization of information².

Vision plays a crucial role in knowledge acquisition, and in the development of skills such as language, communication, and connection with the social and spatial environment, as well as with skills that require hand-eye coordination ${ }^{3-5}$.

Despite the fact that vision is essential in academic activities, today it is acknowledged that learning is a complex brain process, and therefore, a specific visual deficiency is not directly associated with the cause of a learning disorder ${ }^{2,6-8}$.

It has been described that visual disorders and academic problems can coexist ${ }^{2}$. Some children with and without learning difficulties usually avoid activities that involve using near vision because they exhibit symptoms such as blurry vision, diplopia, headaches, a feeling of tightness in the eyes, loss of concentration, and sleepiness ${ }^{1,9-11}$.

Some binocular vision disorders, such as accommodative and convergence insufficiencies, as well as uncorrected refractive errors, can hinder reading and impact academic performance ${ }^{2,11-16}$. Although accommodation plays a key role in vision, it is not assessed systematically in children because this function is supposed to be excellent in them; its average value in children under 10 years is around 14 diopters $^{2,14}$.

Learning difficulties require a multidisciplinary approach for its diagnosis and treatment, which involves teachers, neuropsychologists, physicians from different specialties, and family. Ophthalmological assessment is among the set of tests used to rule out any problems that may interfere with the learning process ${ }^{17}$.

There is little information on the current visual condition of patients with learning difficulties without specific disorders such as dyslexia, and attention deficit hyperactivity disorder (ADHD), among others ${ }^{16}$.

The main objective of this study is to describe the eye disorders and diseases found in a group of Mexican patients with learning difficulties referred for ophthalmological assessment.

\section{Method}

An observational cross-sectional study was conducted with a mestizo population in the city of Monterrey, Nuevo León, Mexico including 69 patients without any clinically evident neurological disorders, aged between 5 and 16 years, and referred to an educational support center for ophthalmological assessment for showing learning difficulties from January 2018 through January 2019.

The variables studied were the presence or absence of any eye disorders and diseases such as refraction errors, accommodative insufficiency, convergence insufficiency, amblyopia, strabismus, color vision disorders, and other ophthalmological conditions. To that end, the following data were collected from their electronic health records: sex, age, visual acuity, cycloplegic refraction, eye motility, sensoriality, stereoacuity, near point of convergence, accommodative amplitudes, intraocular pressure, slit lamp, fundus examination, and diagnosis. All the information was recorded in a database to be subsequently analyzed using descriptive statistics for the clinical and demographic data; frequencies and percentages for qualitative variables; and means and medians (standard deviation and ranges) for quantitative variables depending on their 
distribution. The SPSS Statistics software for Windows, Version 25.0, IBM was used.

The study was approved by the Instituto Tecnológico $y$ de Estudios Superiores Medical School research ethics committee.

The following procedures were performed on all the patients who were assessed: visual acuity test using standardized optotypes according to the patients' ages at a 6-meter distance; assessment of eye motility using the cover-uncover test at a 6-meter distance, and $40 \mathrm{~cm}$ in the primary position to detect the presence of phorias and tropias. Also, versions and ductions were tested through visual follow-up with a fixed object. In addition, the close point of convergence was measured and sensoriality was evaluated using the Worth 4 dot test while stereoacuity was measured using the Random dot test. Color vision was assessed using the Ishihara chart while accommodative amplitudes were measured using Sheard's method. Intraocular pressure was measured with a rebound tonometer. The anterior segment was assessed using a slit lamp to detect conditions on the ocular surface; after applying two drops of an ophthalmic solution of cyclopentolate at $1 \%$ in each eye followed by $8 \mathrm{mg} / \mathrm{mL}$ of tropicamide and $50 \mathrm{mg} / \mathrm{mL}$ of phenylephrine, a cycloplegic refraction procedure was performed. Finally, fundus examination was conducted through indirect ophthalmoscopy.

The presence of a significant refraction error requiring prescription was determined should the following conditions be found: myopia $\geq-0.75 \mathrm{D}$, hypermetropia $\geq+3.50 \mathrm{D}$, astigmatism $\geq-1.00 \mathrm{D}$, and anisometropia $\geq 1.50 \mathrm{D}$ in any type of refractive error ${ }^{6,18-20}$; accommodative insufficiency when the value found was two diopters below the expected accommodation value based on the patient's age using Hofstetter's formula, 15 $(0.25 \times \text { patient's age })^{11,21}$; convergence insufficiency in the presence of exodeviation $>4$ DP plus the presence of a far close point of convergence $\geq 7 \mathrm{~cm}^{11}$; amblyopia based on the criteria established by the American Academy of Ophthalmology22; strabismus in the presence of tropia in the cover-uncover test; color vision disorders if results of the Ishihara test were not normal; and other ophthalmological conditions if other disorders were found in the slit lamp test and the fundus examination.

\section{Results}

The study included data from 69 patients referred for ophthalmological assessment to the pediatric ophthalmology and strabismus unit at the Zambrano
Table 1. Demographic characteristics of the study population

\begin{tabular}{|c|c|}
\hline Characteristic & $N=69$ \\
\hline Mean age (SD), years & $9.3 \pm 3.5$ \\
Sex, n (\%) & \\
Male & 51 \\
Female & 18 \\
\hline
\end{tabular}

SD, standard deviation

Table 2. Ophthalmological diagnoses found

\begin{tabular}{|l|c|}
\hline Diagnosis & N $=69$ \\
\hline Healthy & 31 \\
\hline Significant refractive error & 22 \\
\hline Accommodative insufficiency & 10 \\
\hline Convergence insufficiency & 10 \\
\hline Strabismus & 4 \\
\hline Amblyopia & 4 \\
\hline Color blindness & 4 \\
\hline Others & 10 \\
\hline
\end{tabular}

More than one ophthalmological diagnosis was found in 18 children.

Hellion Hospital from an educational institution after psychopedagogical evaluation due to learning difficulties from January 12018 through January 12019.

The patients' mean age was $9.3 \pm 3.5$ years (range, 5-16 years), 51 of them were boys (Table 1). In 31 of the 69 patients no eye disorders or diseases were found, 22 presented refraction errors that required optical correction, accommodative insufficiency was found in 10 patients, and convergence insufficiency was found in another $10 \mathrm{~A}$ total of 4 patients had strabismus and 4 amblyopia (in 3 of them the cause was strabismus and in 1 of them anisometropia), 4 were diagnosed with color blindness, and 10 had different diagnoses like allergic conjunctivitis, and staphylococcal blepharoconjunctivitis, among others (Table 2, and Fig. 1).

The mean LogMAR visual acuity in the right eye was $0.13( \pm 0.17)$ and $0.12( \pm 0.17)$ in the left eye. Of the 22 patients with significant refraction errors who required optical correction, 6 had hypermetropia, 11 hypermetropic astigmatism, 3 had myopia, and 2 had myopic astigmatism (Table 3).

Of the 10 patients with accommodative insufficiency, 6 had significant refractive errors that required optical 


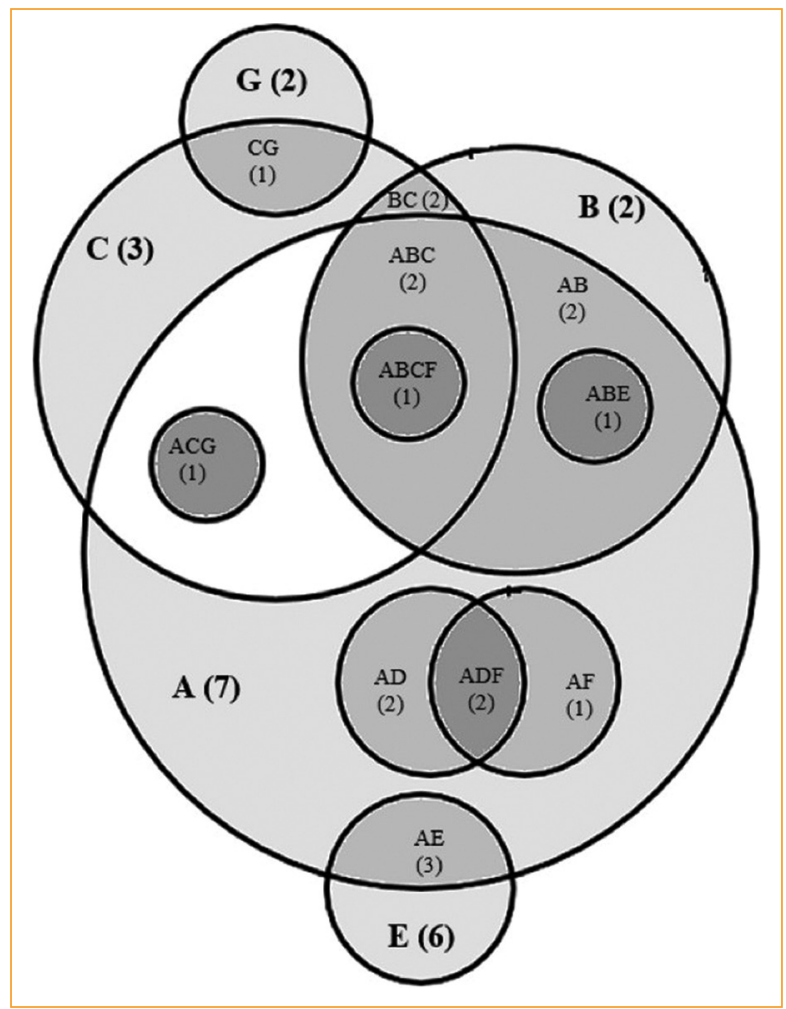

Figure 1. A: significant refractive error. B: accommodative insufficiency. C: convergence insufficiency. D: amblyopia. E: others. F: strabismus. G: color blindness. The number of cases is shown between brackets.

correction, five had added convergence insufficiency and one had strabismus. The mean accommodation amplitude in the patients diagnosed with accommodative insufficiency was -7.07 diopters $( \pm 1.45)$ in the right eye and -7.75 diopters $( \pm 1.16)$ in the left eye with a mean difference of 4.88 diopters (4 to 6.5 ) according to what would correspond to them according to their age-based on Hofstetter's formula. The mean accommodation of all the children studied was 10.14 $\mathrm{D}( \pm 1.78)$ in the right eye and 10.23 $D( \pm 1.58)$ in the left eye (Table 4, and Fig. 2).

\section{Discussion}

The results presented correspond to a small mestizo population sample from the northeast of Mexico, and more than half of the patients had eye disorders and diseases that could hinder their academic activities $^{2,8,16}$.

The patients' mean age was $9.3 \pm 3.5$ years (range, 5 -16 years). The current recommendations on eye
Table 3. Refraction errors

\begin{tabular}{|l|c|}
\hline Refraction error & N $=22$ \\
\hline Hyperopia & 6 \\
\hline Hyperopic astigmatism & 11 \\
\hline Myopia & 3 \\
\hline Myopic astigmatism & 2 \\
\hline
\end{tabular}

Table 4. Accommodative amplitudes found in children with accommodative insufficiency

\begin{tabular}{|l|c|}
\hline Accommodative insufficiency $(\mathrm{N}=10)$ & Mean (SD) \\
\hline Accommodative amplitude in the right eye & $7.07( \pm 1.45)$ \\
\hline Accommodative amplitude in the left eye & $7.75( \pm 1.16)$ \\
\hline Expected difference based on age & $4.88(4-6.5)$ \\
\hline
\end{tabular}

SD, standard deviation.

examinations in children clearly state the importance of performing these examinations early and regularly ${ }^{14}$. Most patients were boys; however, another study conducted in patients with learning difficulties found no significant differences when learning disorders are considered in genera ${ }^{23}$.

It has been described that $5 \%$ to $25 \%$ of school-age patients have some type of eye disease or disorder ${ }^{2,18}$. The main eye disorders and diseases found were refraction errors in 22 of the 69 participants, which amounts to one-third of the study sample. Prevalence varies depending on age and on the population studied; for example, in India, a meta-analysis revealed that the overall prevalence of refraction errors in children was $8 \%$, specifically myopia $\geq 2 \mathrm{D}$ in $5.3 \%$ of the population, hypermetropia $\geq 2$ D in $4 \%$ of the population, followed by astigmatism $\geq 2 \mathrm{D}$ in $5.4 \%$ of the population ${ }^{24}$. The American Academy of Ophthalmology, in its clinical practice guidelines on the management of ophthalmological assessments in children published back in 2017, reported a prevalence of myopia $\geq-0.75 \mathrm{D}$ in children aged 5 to 17 years from $0.7 \%$ to $9 \%$, of hypermetropia $\geq+3.00 \mathrm{D}$ from $4 \%$ to $9 \%$, and a prevalence of astigmatism $\geq 1.5 \mathrm{D}$ from $4 \%$ to $11 \%$ in the pediatric population ${ }^{18}$. Regarding the rate of strabismus and amblyopia, it was also slightly higher compared to that reported in the scientific literature available ${ }^{18}$.

It is well known that accommodative and convergence insufficiencies are uncommon in children ${ }^{2,16}$. 


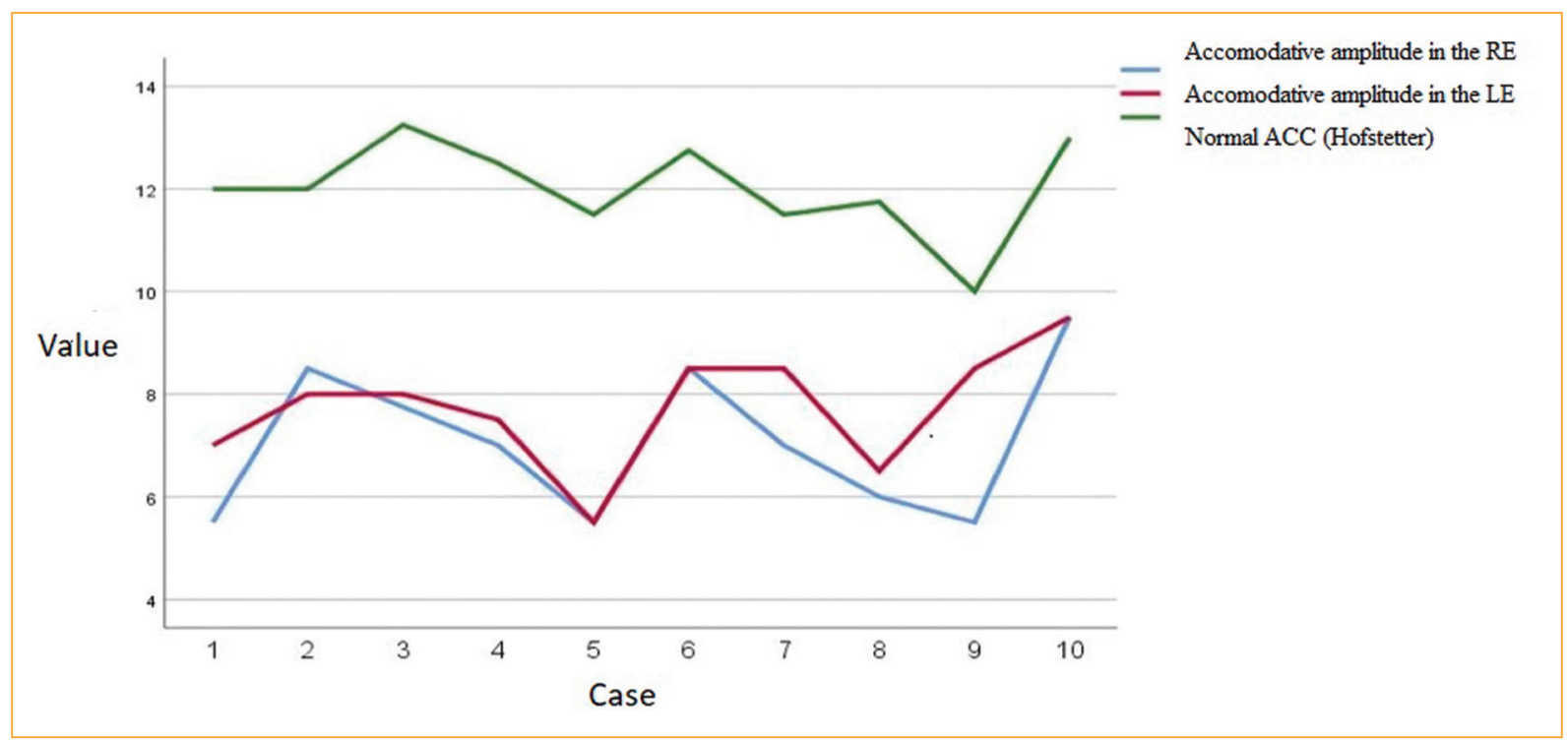

Figure 2. The measured value of accommodative amplitudes in children with accommodative insufficiency in diopters and the expected value in each case based on their age.

A study conducted among 292 Portuguese children aged 10 to 14 years found a $6.8 \%$ prevalence of convergence insufficiency and a $10 \%$ accommodative insufficiency rate, and a $3 \%$ rate of coexistence of both ${ }^{21}$. Another study conducted in South Africa reported a $4.3 \%$ prevalence of convergence insufficiency ${ }^{25}$, and another one conducted in Ecuador found a 16\% prevalence of accommodative insufficiency ${ }^{26}$. In this study we found that 10 out of 69 patients (14.5\%) had accommodative insufficiency, and $10(14.5 \%)$ convergence insufficiency, and in half the cases coexistence of both, similar to the findings reported by Davis, et al. ${ }^{11}$. In their population sample, they found a greater prevalence of both accommodative and convergence insufficiencies, and coexistence of both in half of the total number of cases reported. We think that future research in this area is necessary to determine whether this is a risk factor or not for developing learning difficulties since they have both been described as causes of asthenopic symptoms in the pediatric population $^{16,21}$.

\section{Conclusions}

This study found an important number of eye disorders and diseases; therefore, we consider it is important to promote regular eye testing programs since infancy, as well as thorough ophthalmological examinations including vergences and accommodation in children with academic difficulties to identify visual disorders that could interfere with the learning process.

Refraction errors, accommodative insufficiency, and convergence insufficiency were the eye disorders and diseases more commonly found in this population. The coexistence of accommodative insufficiency and convergence insufficiency was representative, and both require further research.

\section{Funding}

The authors declare that for this research no external sources of financing have been used for the conduct of this study.

\section{Conflicts of interest}

The authors declare not having any conflict of interest.

\section{Ethical disclosures}

Protection of human subjects and animals in research. The authors declare that no experiments were performed on humans or animals for this study.

Patients' data protection. The authors declare that they have followed the protocols of their work center on the publication of patient data.

Right to privacy and informed consent. Due to the nature of the study, observational retrospective, 


\section{consent was not used requested. Personal data of the subjects was protected at all times.}

\section{References}

1. Dusek WA, Pierscionek BK, McClelland JF. An evaluation of clinica treatment of convergence insufficiency for children with reading difficulties. BMC Ophthalmol. 2011;11:21

2. Handler SM, Fierson WM. Reading difficulties and the pediatric ophthalmologist. J AAPOS. 2017;21:436-42.

3. World Health Organization. World report on vision. Suiza: WHO; 2019 Available at: https://apps.who.int/iris/bitstream/handle/10665/328717/978 9241516570-eng.pdf

4. Van Leeuwen LM, Rainey L, Kef S, Van Rens GHMB, Van Nispen RMA. Investigating rehabilitation needs of visually impaired young adults according to the International Classification of Functioning, Disability and Health. Acta Ophthalmol. 2015;93:642-50.

5. Day S. Normal and abnormal visual development. En: Pediatric ophthalmology. Oxford UK: Blackwell Science; 1997. p. 13-28.

6. Healy A, Erenberg G, Kaminer RK, La Camera R, Nackashi JA, Poncher JR, et al. Learning disabilities, dyslexia, and vision. Pediatrics. 1992;90:124-6.

7. Flax N. Visual function in learning disabilities. J Learn Disabil. 1968:1:551-6.

8. Creavin AL, Lingam R, Steer C, Williams C. Ophthalmic abnormalities and reading impairment. Pediatrics. 2015;135:1057-65.

9. Borsting E, Mitchell GL, Kulp MT, Scheiman M, Amster DM, Cotter S, et al. Improvement in academic behaviors following successful. Optom Vis Sci. 2012;89:12-8.

10. Scheiman M, Cotter S, Mitchell GL, Kulp M, Rouse M, Hertle R, et al. Randomized clinical trial of treatments for symptomatic convergence insufficiency in children. Arch Ophthalmol. 2008;126:1336-49.

11. Davis AL, Harvey EM, Twelker JD, Miller JM, Leonard-Green T, Campus I. Convergence insufficiency, accommodative insufficiency, visual symptoms, and astigmatism in Tohono O'odham students. J Ophthalmol. 2016;2016:6963976.

12. Scheiman M, Rouse M, Kulp MT, Cotter S, Hertle R, Lynn Mitchell G, et al. Treatment of convergence insufficiency in childhood: a current perspective NIH Public Access Author Manuscript. Optom Vis Sci. 2009;86:420-8.
13. Bruce AS, Lakkis G. Accommodation deficiency in healthy young individuals. J Pediatr Ophthalmol Strabismus. 1990;27:327.

14. Prangen AD. Subnormal accommodation. Trans Am Ophthalmol Soc. 1931;29:372-91.

15. Cacho-Martínez P, Cantó-Cerdán M, Carbonell-Bonete S, García-Muñoz A. Characterization of visual symptomatology associated with refractive, accommodative, and binocular anomalies. J Ophthalmol. 2015;2015:31-42

16. Phillips PH. Pediatric ophthalmology and childhood reading difficulties: convergence insufficiency: relationship to reading and academic performance. J AAPOS. 2017;21:444-6.e1.

17. Slavin RE, Collins ME, Repka MX, Friedman DS, Mudie LI, Owoeye JO, et al. In plain sight: reading outcomes of providing eyeglasses to disadvantaged children. J Educ Students Placed Risk. 2018;23:250-8.

18. Wallace DK, Morse CL, Melia M, Sprunger DT, Repka MX, Lee KA, et al. Pediatric Eye Evaluations Preferred Practice Pattern®: I. Vision screening in the primary care and community setting; II. Comprehensive ophthalmic examination. Ophthalmology. 2018;125:184-227.

19. Macewen C. The Royal College of Ophthalmologists Seminar Programme organised and Chaired by The Royal College of Physicians. 2013;(March):4-5.

20. Leat SJ. To prescribe or not to prescribe? Guidelines for spectacle prescribing in infants and children. Clin Exp Optom. 2011;94:514-27.

21. Nunes AF, Monteiro PML, Ferreira FBP, Nunes AS. Convergence insufficiency and accommodative insufficiency in children. BMC Ophthalmol. 2019;19:1-8

22. Wallace DK, Repka MX, Lee KA, Melia M, Christiansen SP, Morse CL, et al. Amblyopia Preferred Practice Pattern®. Ophthalmology. 2018; $125: 105-42$

23. Moll K, Kunze S, Neuhoff N, Bruder J, Schulte-Körne G. Specific learning disorder: prevalence and gender differences. PLoS One. 2014;9:e103537.

24. Sheeladevi S, Seelam B, Nukella PB, Modi A, Ali R, Keay L. Prevalence of refractive errors in children in India: a systematic review. Clin Exp Optom. 2018;101:495-503.

25. Wajuihian SO, Hansraj R. Anomalías de vergencia en una muestra de estudiantes de secundaria de Sudáfrica. J Optom. 2016;9:246-57.

26. Legrá Nápoles S, Galarza Núñez JL, Martínez Herrera CP, Gallo González M. Disfunciones acomodativas en estudiantes no estrábicos de la Unidad Educativa Arturo Borja, Orellana, Ecuador. Rev Conrado. 2019;15:110-24 